AGRICULTURE AND BIOLOGY JOURNAL OF NORTH AMERICA

ISSN Print: 2151-7517, ISSN Online: 2151-7525, doi:10.5251/abjna.2011.2.5.867.871

(C) 2011, ScienceHu $\beta$, http://www.scihub.org/ABJNA

\title{
Biodiversity and agricultural productivity enhancement in Nigeria: application of processed Moringa oleifera seeds for improved organic farming
}

\author{
S. A. Emmanuel, B.S. Emmanuel, S. G Zaku and S.A Thomas \\ ${ }^{1}$ Nigerian Institute of International Affair Victoria Island Lagos \\ ${ }^{2}$ Sheda science and Technology Complex PMB 186 Garki Abuja \\ Email sawemmy @yahoo.com
}

\begin{abstract}
A mini field trial on the use and bio-decomposition of moringa oleifera seed cake as organic fertilzer was carried out in the Sheda Science and Technology Complex. The field investigation established the fact that organic farming based on the use of processed Moringa Oleifera seed as fertilizer on a maize farm achieved significant improvement on soil nutrients as shown in the plant yield as compared to the control. This integrated biodiversity management approach to agriculture will afford the farmers in developing societies like Nigeria ready sources of organic fertilizers with a view to optimizing crop production and environmental protection and ultimately reduce poverty.
\end{abstract}

Keywords: Biodiversity, Organic Farming, Moringa Oleifera, Ecosystem, Environment, Poverty, Agriculture, Fertilizer

\section{INTRODUCTION}

Nigeria is one of the countries in Sub-Saharan Africa (SSA) where self-sufficiency in food production remains a critical challenge even in the absence of wars and natural disasters (Alimi et al, 2006). The importance of agriculture in Nigeria's economy cannot be understated. Farming and livestock rearing is the main livelihood for over 70 percent of households in the country. In 2008, agriculture contributed 42 percent of the country's GDP, significantly higher than the 18 percent derived from petroleum and natural gas production (Banful, Nkonya and Oboh, 2009). However, the country's promising agricultural potential has not been realized. In all likelihood, low fertilizer use is a major factor in explaining the stagnant agricultural productivity in Nigeria (Banful et al, 2009).

Biodiversity is the variety of living organisms considered at the genetic, species and ecosystem or landscape level. It includes not only plant and animal as we commonly know them, but very importantly micro-organism (Okali, 2005). The integrated biodiversity management approach to agriculture in Nigeria will ensure food security and alleviate poverty. No doubt, agriculture is the most important user of environmental services including water, forests, pastures and soil nutrients. Hence, intensive land use without appropriate soil management practices leads to environmental degradation. A sustainable agriculture has been defined to be one that over a long term enhances environmental quality and resource base on which agriculture depends; provides for basic human food and fibre needs; is economically viable, and enhances the quality of life of farmers and society as a whole (CGIAR, 1988). Modern organic agriculture builds on principles for improving soil fertility through incorporation of legumes and compost, strengthening ecological support-functions and using natural regulation and crop diversity to prevent pest and diseases (Okoh, 2010).

The fragility and high susceptibility of the soils in Nigeria to degradation and loss of nutrients make augmentation through the use of fertilizers necessary to obtain reasonable crop yield (Alimi et al, 2006). The Federal Government of Nigeria (FGN) recognized that the nation's food security can be improved mainly through increasing agricultural productivity, and has instituted various interventions aimed at precipitating widespread adaptation of intensive farming technologies (Banful et al, 2009). Intensive agriculture has increased crop yields but also posed severe environmental problems. Sustainable agriculture would ideally produce good crop yields with minimal impact on ecological factors 
such as soil fertility. A fertile soil provides essential nutrients for crop plant growth, supports a diverse and active biotic community, exhibits a typical soil structure, and allows for an undisturbed decomposition (Mäder et al, 2002). Soil organisms contribute a wide range of essential services to the sustainable functioning of all ecosystems by acting as the primary driving agents of nutrient cycling; regulating the dynamics of soil organic matter, soil carbon sequestration and greenhouse gas emission; modifying soil physical structure and water regime; enhancing the amount and efficiency of nutrient acquisition by plants; and enhancing plant health. These services are not only essential to the functioning of natural ecosystems but also constitute an important resource for the sustainable management of agricultural systems (FAO, 2010).

However Moringa is one of the most useful tropical trees. The relative ease with which it propagates through both sexual and asexual means and its low demand for soil nutrients and water after being planted makes its production and management easy. Introduction of this plant into a farm which has a biodiverse environment can be beneficial for both the owner of the farm and the surrounding ecosystem (Foidl et al 2001). Organic fertilizers derived from Moringa Oliefera seed processed with the right procedure can increase the soil aeration and richness of indigenous invertebrates, specialized endangered soil species, beneficial arthropods, earthworms, symbionts and microbes (FAO, 2010).

The main focus of this paper is to study the effect of moringa oleifera seed cake as a fertilizer and its decomposition period on plant productivity. A search of the literature indicates that not much information has been reported on the use of the seed cake of moringa oleifera.

Experimental trial: The soil at the study site is a moderately drained loamy soil. The climate is tropical (average temperature was 35.0 degree Celsius and average rainfall is $\mathbf{1 1 4 0}$ millimeters per year) (OnlineNigeria, 2009).

The experimental design included: (a) harvesting of the seed pods (b) extraction of oil from seed (c) drying of organic fertilizer from the seed cake. In addition, three cropping seasons were investigated.

Preparation of seed cake: The seed pods were obtained from the moringa oleifera experimental farm within the Complex. They were dehusked and pulverized. The oil in the seed was extracted by aqueous extraction as stated by Price (2007) and by hexane extraction. The seed cake was sun dried and pulverized. It was then stored in a polyethylene bag.

Field preparation : At the onset of rain a portion of field ( 8 by 8 feet $\times 4$ ) was cleared and prepared for a mini field trial.

After clearing the cake was applied to the plots. Maize seeds were planted 6 days after application. A control plot was also prepared alongside the sample plots.

The following physical parameters were determined in the course of the work;

- No of germinated seeds

- Plants height

- Number of leaves produced

- Plant thickness

- Weight of fruit produced

- Number of fruit on stalk

- Leaf girth

The measurements were taken 10 day after germination and at 2 weeks interval until maturity.

Elemental analysis: $1.0 \mathrm{~g}$ of the seed cake sample was weighed and digested with nitric/ $/ \mathrm{HClO}_{4}$ in the ratio $5: 1$ in a $100 \mathrm{ml}$ beaker until a cloud of white fume evolved. It was filtered and diluted to $100 \mathrm{ml}$ with distilled deionised water in a $100 \mathrm{ml}$ volumetric flask and stored in a polyethylene bottle. Working standard solutions of $\mathrm{Ca}, \mathrm{Mg}, \mathrm{Fe}, \mathrm{Mn}, \mathrm{Zn}, \mathrm{Cu}$, were prepared from stock standard solution (1000ppm) and the absorbance for each element was obtained using atomic absorption spectrometer (AAS) 969 UNICAM (Omojola, 1993). This was done against a blank. The element concentration was determined from the calibration curve. The concentration of nitrogen in the sample was determined by Kjehdal method and phosphorus by gravimetric method while sodium and potassium were determined by flame photometer (Omojola, 1993).

Microbial colony count: $1 \mathrm{~g}$ of sample was poured into a test tube and $9 \mathrm{ml}$ sterilized distilled water was added to it. It was shaken on a vortex. $1 \mathrm{ml}$ of this was measured and a serial dilution was done. Dilution 3 was inoculated on a nutrient agar plate and incubated at $37{ }^{\circ} \mathrm{C}$ for 24 hours. The number of colonies on plate was counted and calculated as cfu/ml.

\section{RESULTS AND DISCUSSIONS}

The result of the experiment is presented on Table 1. The maize yield on the Moringa fertilizer plot produced the best result, that is, an average of 
$330.7 \mathrm{~cm}$ height at maturity; average of 17 leaves; average of $337.0 \mathrm{~g}$ weight of wet cob and an average of $205 \mathrm{~g}$ weight of dry cob as compared to the control. Figure 1 showed the growth rate in height of the maize plant as compared to the control. This is an indication that within the period of application, planting and maturity of plants the fertilizer had decomposed and made mineral nutrient available for plant use as compared to the control. Other organic fertilizers from plant and animal sources require a long period for decomposition (Villablanca, 2007) before planting. But this study has shown that the moringa oleifera seed cake can be used without long pre-decomposition period of the organic matter to give an improved plant yield. It also shows that there was no adverse effect on the plant.

Table 1: Result of Moringa seed cake as fertilizer on maize cultivation: Average of 3 years field trial

\begin{tabular}{|c|c|c|}
\hline Parameters & $\begin{array}{l}\text { Moringa seed } \\
\text { cake Fertilizer }\end{array}$ & $\begin{array}{c}\text { Control } \\
\text { Cultivation } \\
\text { (Without } \\
\text { Fertilizer) }\end{array}$ \\
\hline $\begin{array}{l}\% \text { of germinated } \\
\text { seed }\end{array}$ & 99 & 98 \\
\hline $\begin{array}{l}\text { Plant height } 10 \\
\text { days after } \\
\text { germination }(\mathrm{cm})\end{array}$ & 17.24 & 12.6 \\
\hline $\begin{array}{l}\text { Leaf girth at } \\
\text { maturity }(\mathrm{cm})\end{array}$ & 10.2 & 8.4 \\
\hline $\begin{array}{l}\text { Height at maturity } \\
(\mathrm{cm})\end{array}$ & 330.7 & 198.7 \\
\hline No of Leaves & 17 & 14 \\
\hline Thickness (mm) & 32.2 & 27.6 \\
\hline $\begin{array}{l}\text { Weight of Wet } \\
\text { Cobs }(\mathrm{g})\end{array}$ & 377 & 318 \\
\hline $\begin{array}{lll}\text { Weight } & \text { of } & \text { Dry } \\
\text { Cobs(g) } & & \\
\end{array}$ & 205 & 148 \\
\hline $\begin{array}{l}\text { No of Cobs per } \\
\text { stalk }\end{array}$ & 2,1 & 1 \\
\hline
\end{tabular}

It was also observed in the course of the work that the seed cake that was not dried immediately grew a lot of colony of microbes overnight. This may be attributed to the high protein content of the seed (Price, 2007); which may also be responsible for its short decomposition period. A study of the microbial load of the seed cake is shown in Table 3. Microbial activities on organic matter have been found to be useful in nature farming and organic agriculture and it is being widely applied (Higa and Parr, 1994). The activities of microorganism on the decomposition of the organic seed cake in this experiment appeared to be constructive decomposition as the growth and yield of the crop increased when compared to the control (Fig 1). This suggests that the activity of pathogenic micro organism as shown in other organic matter source is greatly reduced in the moringa oleifera seed cake fertilizer.

Effective management of soil organic matter as shown by the mini field experiment can provide the basis for productive organic farming and sustainable agriculture. Organic farming based on the use of processed Moringa Oleifera seed cake as fertilizer on a maize farm achieved significant improvement on soil nutrients within a short period of time on its application.

Table 2: some elemental composition of moringa seed cake

\begin{tabular}{|l|l|}
\hline Element & Composition in ppm \\
\hline $\mathrm{Ca}$ & $25.60 \pm 0.32$ \\
\hline $\mathrm{Fe}$ & $0.81 \pm 1.02$ \\
\hline $\mathrm{Zn}$ & $1.61 \pm 0.21$ \\
\hline $\mathrm{Na}$ & $1.02 \pm 0.60$ \\
\hline $\mathrm{K}$ & $5.93 \pm 0.98$ \\
\hline $\mathrm{Cu}$ & $2.48 \pm 0.03$ \\
\hline $\mathrm{Mg}$ & $0.45 \pm 0.01$ \\
\hline $\mathrm{P}(\%)$ & $14.82 \pm 0.15$ \\
\hline $\mathrm{N}(\%)$ & $2.60 \pm 0.54$ \\
\hline $\mathrm{H}$ & $7.7 \pm 0.54$ \\
\hline
\end{tabular}

The results are means of triplicate determination \pm standard deviation

Table 3: Microbial load of seed cake before application to field $\mathrm{cfu} / \mathrm{ml}$ :

\begin{tabular}{|c|l|}
\hline Whole seed exposed to air & $5.8 \times 10^{\prime}$ \\
\hline Defatted seed & $2.5 \times 10^{\prime}$ \\
\hline
\end{tabular}




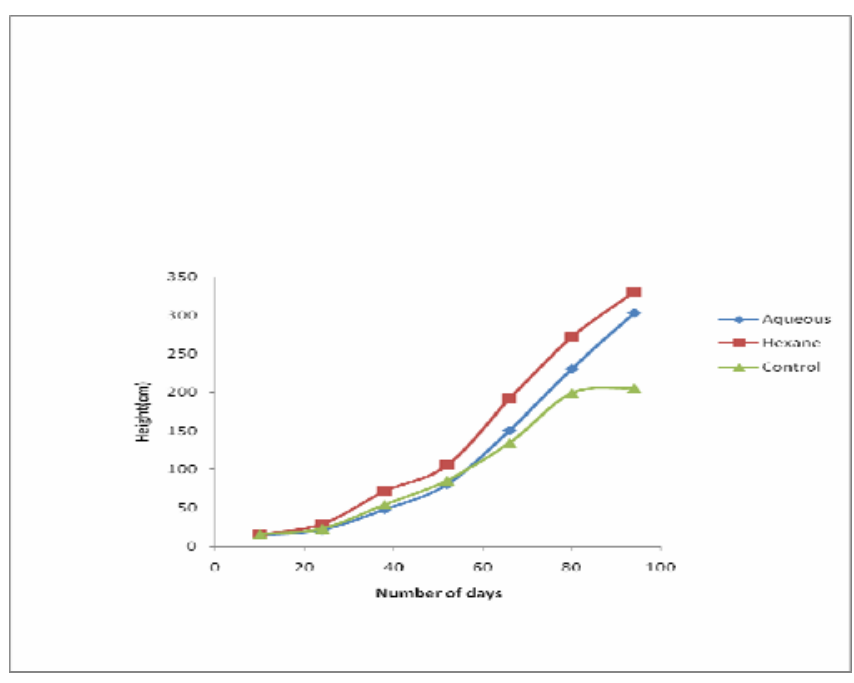

Fig 1: Graph of growth rate in height of maize plant

\section{CONCLUSION AND RECOMMENDATIONS:}

In conclusion, organic agriculture through biodiversity manages locally available resources to optimize competition for food and space between different plant and animal species. By restraining from using mineral/inorganic fertilizers, synthetic pesticides, pharmaceuticals and genetically-modified seeds and breeds, biodiversity is relied upon to maintain soil fertility and to prevent pests and diseases.

All the values of biodiversity can be exploited to gain benefits for boosting agricultural productivity. This paper is of the position that the use of the biodiversity properties of Moringa Oleifera seed cake for soil fertilization, leads to plant growth enhancement within a short period of its application as compared to other organic matters from animal dung and plant compost which require long periods for decomposition and cautious use (Villablanca, 2007).

In a detailed analysis of factors limiting agricultural productivity in sub- Saharan Africa, Sanchez et al. (1997) drew attention to the fact that the bulk of food in Africa is produced on small-scale farms by women. Under these conditions, they noted that, the three main determinants for overcoming rural poverty are (i) an enabling policy environment for the smallholder farming sector, (ii) reversing soil fertility depletion and (iii) intensifying and diversifying land use with high value products. They pointed out that these three goals can be attained in Africa with modern organic agricultural practices. It is shown through this study that the use of processed Moringa Oleifera seed can help to reverse soil fertility depletion. The adoption of the organic farming practice using the biodiversity components of the Moringa trees for improved agricultural productivity is therefore recommended due to the following benefits:

(a) Organic fertilizers from processed Moringa seed cake can easily be packaged locally and commercially distributed to intending organic farmers

(b) Moringa fertilizers can easily be produced using locally available technologies

(c) Abundant raw material for organic fertilizer can easily be made available through largescale plantation of Moringa trees

(d) In particular, all the 36 States of Nigeria including Abuja, the Federal Capital Territory have the potential for Moringa tree plantation as it is best grown in the tropics.

\section{REFERENCES}

Alimi, T., Ajewole, O.C., O.O. Olubode-Awosola, O. O., Idowu, E. O.,(2006);

Economic rationale of commercial organic fertilizer technology in vegetable production in Osun State of Nigeria; Journal of Applied Horticulture, p159-164, July-Dec., 2006

Banful, A. B., Nkonya, E., Oboh, V., (2009); Constraints to Fertilizer Use in Nigeria: Perspectives and Insights from the Agricultural Extension Service; IFPRI; http://www.ifpri.org/sites/default/files/publications/nssp br06.pdf; Accessed: June 16, 2010

Biodiversity and Organic Agriculture: An Example of Sustainable Use of Biodiversity; ftp://ftp.fao.org/fao/010/i0112e/i0112e09.pdf; FAO, Feburary 2010.

CGIAR (Consultative Group on International Agricultural Research), 1988; Sustainable Agricultural Production: Implication for International Agricultural Research TAC report (AGRI/TAC:/AR/ 8722 Rev.2) Washington D.C. USA.

FAO (2010) Soil Biota and Biodiversity: "The "Root" of Sustainable Development"; ftp://ftp.fao.org/docrep/fao/ 010/i0112e/i0112e07.pdf; Accessed: February 2010.

Foidl, N, Makkar, H.P.S., Becker, K., (2001); "The Potential of Moringa Oleifera for Agricultural and Industrial Uses";http://www.ruralsementes.com.br/produtos/; 2001; pp 6-7; Accessed: June 16, 2010

Leakey, R. R. B., Wilson J. \& Deans, J.D. (1999;"Domestication of Trees for Aqroforestry in Dry lands" Annals of Arid Zone, 1999 
Mäder P., Fließbach A., Dubois D., Gunst L., Fried P., Niggli U, (2002), "Soil Fertility and Biodiversity in Organic Farming"; American Association for the Advancement of Science, New Series, Vol. 296, No. 5573 pp. 1694-1697

Martin L. Price (2007); Echo Technical Note.

National Bureau of Statistics, Abuja Nigeria;

Omojola M.O, (1993); Modification of urea with maize cob waste for slow release nitrogen fertilizer; A Ph.D thesis submitted to the Department of Chemistry, Ahamdu Bello University, pp1-2, 42, 111-116.

Okali, D.U.U, (2005); "Biodiversity and Poverty Alleviation"; NEST, Ibadan; 2005

Okoh G, (2010);, "Organic Food - Nigeria Should not be left behind": http://www.thisdayonline.com/nview.php?id=175206, June 16, 2010

Okoh G, (2010); "Nigeria loses \$46bn to Organic Farming"; http://www.thisdayonline.com/nview.php?id=175208; Accessed: June 16, 2010
OnlineNigeria,(2009): http://www.onlinenigeria.com/links/abujaadv.asp?blurb =388; Accessed: June 16, 2010

Pimentel, D, Hepperly P, Hanson J, Douds, D., Rita Seidel, R. (2005); "Environmental, Energetic, and Economic Comparisons of Organic and Conventional Farming Systems"; BioScience, Vol. 55, No. 7, pp. 573-582.

Sanchez, P.A., Buresh, R.J. \& Leakey, R.R.B. (1997); "Trees, soils and food security"; Philosophical Transactions: Biological Sciences 352: 949961

Teruo Higa and James F. Parr, (1994); Beneficial and effective Microorganisms for a sustainable agriculture and environment: International Nature Farming Research Center Atami Japan

Villablanca, E., (2007); Why Organic Fertilizers are Safer to Use than Inorganic Fertlizers; http://www.associatedcontent.com/article/333446/why_ organic_fertilizers_are_safer_to_pg2.html?cat=32; Accessed: June 16, 2010 